\title{
The effects of the EEC directive on the status of bovine semen in the EEC
}

\author{
M Philpott \\ Avoncroft Cattle Breeders Limited, B60 3AS Bromsgrove, UK
}

(Received 31 May 1991; accepted 20 July 1992)

\begin{abstract}
Summary - With the aim of enabling free movement of frozen bovine semen between member states, the Directive sets out a standard set of rules governing the entry of bulls into registered artificial insemination (Al) centres, the processing of their semen and its storage and distribution. Until the implementation of the Directive in January 1990, all health certification allowing importation of semen had varied from country to country. Basically, there are no fundamental changes to the system already used by many Western European countries. Pre-entry health testing is followed by mandatory isolation on stud for a further month, and official testing of the whole stud is demanded annually. Particular points of debate include the option for foot and mouth culture of sample straws for trade with countries that have not regularly vaccinated, the blanket treatment of all donor sires with streptomycin for protection against Leptospira serotypes, and the elimination of IBR serologically positive bulls. The creation of this so-called registered semen, freely marketable within and between member states, has raised unanswered questions about the use of semen collected outside the Directive. It must be stored separately from registered semen, and the legal demand for no barriers to trade after 1992 and a neat elimination of all non-registered semen must be tempered. There is semen of young progeny bulls and minor and rare breeds that will be lost to the industry if its views are not heeded. The importation of semen from third countries is currently under bilateral arrangements with individual Member States. Negotiations continue on the Directive's rules for importing from such third countries, without giving them preferential treatment. The Directive only addresses the question of health. Quality control standardisation is more difficult, and will only be practicable when more meaningful laboratory tests that correlate well with fertility are available.
\end{abstract}

\section{semen / EEC / artificial insemination / bovine / health}

Résumé - Effets des directives européennes sur le statut légal de la semence bovine dans la CEE. Dans le but d'aboutir à une liberté de circulation de la semence bovine congelée entre les différents pays membres, la Directive met en avant une série standard de règles qui organisent l'entrée des taureaux dans les centres d'IA, le conditionnement de leur semence, son stockage et sa distribution. Jusqu'à l'application de cette directive en janvier 1990, toutes les règles sanitaires permettant l'importation de semence variaient d'un pays à l'autre. Sur le fond, il n'y a pas de changement fondamental du système déja utilisé par beaucoup de pays de l'Europe de l'Ouest. Un test sanitaire avant l'entrée est suivi par l'isolement dans le centre pour un mois supplémentaire et un test officiel annuel est requis. Les points précis qui sont débattus comprennent une option pour la culture de mise en évidence de la fièvre aphteuse dans des paillettes échantillons pour les échanges avec les pays n'ayant pas régulièrement vacciné, le traitement de couverture de tous les mâles producteurs avec la streptomycine pour la protection contre les sérotypes de la leptospirose et l'élimination 
des taureaux sérologiquement positifs pour l'IBR. La création de cette semence ainsi certifiée, commercialisable librement dans et entre les états membres, a fait apparaître des questions non résolues à propos de l'utilisation de semence collectée en ne suivant pas la directive. Elle doit être stockée séparément de la semence certifiée, et la demande légale de suppression des barrières commerciales après 1992 ainsi qu'une élimination pure et simple de toute la semence non certifiée doit cependant être prise avec prudence. II existe de la semence de jeunes taureaux en testage et de races mineures ou rares qui seront perdues pour la profession si les vues de celle-ci ne sont pas prises en compte. L'importation de semence de pays tiers est actuellement en cours de discussions bilatérales avec des pays membres pris individuellement. Les négociations continuent sur les règles de la directive à propos des importations en provenance de ces pays tiers, sans qu'il leur soit donné de traitement préférentiel. La directive se préoccupe seulement de la santé. Une standardisation des contrôles de qualité est plus difficile et ne sera possible que lorsque des tests de laboratoires significatifs, ayant une bonne corrélation avec la fertilité, seront disponibles.

semence / CEE / insémination artificielle / bovin / santé

\section{INTRODUCTION}

The Semen Directive 88/407 aims to standardize the minimum health standards of donor bulls and the processing, storing and distribution of frozen semen from these sires. It came into operation in January 1990 as part of the Community legislation being built into national legislation before the target date for the single market of 1 January 1993.

In coming to this decision it was agreed that a majority vote at the Council of Ministers would be sufficient for decision making. Depending on one's point of view, one can see this as outflanking would-be obstructionists or rendering it impossible to stand out against a proposal with which one disagrees fundamentally (Porter, 1990).

Before 1990 each member state had its own set of rules, which in most cases covered fundamental health control with supervision by an independent authority. However, veterinary authorities in different member states laid varying emphasis on moving livestock onto centres, the health tests required, quarantine of semen, etc. To give confidence in movement of semen between Member States, a common code of practice was necessary.
The directive may be summarized in principle thus:

1) an officially approved semen collection centre on an EEC registered list and under permanent veterinary supervision;

2) defined health status of the donor sires;

3) a quarantine period before collection of semen;

4) regular inspection by the approved authority twice per year;

5) rules for collecting, processing, storing and transporting semen;

6) standardization of health certification;

7) a complaints procedure.

\section{HEALTH STATUS OF DONOR SIRES}

It is appropriate at this stage to look more closely at No 2 , the health status of donor sires.

In summary, the requirements agreed upon are as follows:

- sires from tuberculosis- and brucellosisfree herds;

- to be tested negative prior to entry for tuberculosis, brucellosis, bovine leukosis, IBR, BVD for antigen. No test is specified for campylobacter or trichomoniasis; 
- after movement to isolation on the stud premises, to be tested for brucellosis, IBR and campylobacter and trichomoniasis. They are also to receive a treatment with streptomycin on 2 occasions at a 14-d interval, with a dosage of $25 \mathrm{mg} / \mathrm{kg}$;

- the semen collection centre itself must be declared free from foot and mouth disease from 3 months prior to collection to 1 month post collection, and with no outbreak of the disease within $30 \mathrm{~d}$ in an area of $10 \mathrm{~km}$ radius. In the case of other notifiable disease, the stud itself must be declared free from 1 month before to 1 month after collections;

- annual testing to be carried out for tuberculosis, brucellosis, bovine leukosis, IBR and campylobacter, and there are restrictions should reactors be demonstrated.

It is pertinent to examine some of the more contentious issues.

\section{Foot and mouth disease and other epizootic disease}

Three countries in the Community have in the past not vaccinated against this disease, namely Denmark, Ireland and the UK. Vaccinated cattle have not been imported by these member states from other countries in the community for fear of the carrier state. Until the implementation of the Directive, semen from vaccinated bulls was also not admitted. With certain rules about the timing of foot and mouth vaccination, member states can no longer prohibit entry of such semen, but there is the option to test $10 \%$ of an ejaculate for the presence of virus. This has opened the door for a free movement of progeny tested semen.

Thus, in 1989 there was no importation of semen from France through our $\mathrm{CO}$ operative in the UK. In 1990 nearly 40000 straws were imported.
Plans to cease vaccination are underway, and by 1992 the necessity for virus testing of ejaculates will be phased out.

Where another epizootic disease arises that may present a health threat by way of frozen semen, article 15 does allow the prohibition of movement of such semen from the area in question. Hare (1985) has set out a useful table illustrating diseases likely to be transmitted via semen.

Although in Europe we tend to highlight the importance of foot and mouth disease, blue tongue vectors exist on the southern boundaries of some member states; and, rather alarmingly, bovine pleuropneumonia has been reported in northern Italy as well as Portugal. This illustrates the necessity for vigilance and prompt reporting.

\section{IBR or infectious broncho- rhinotracheitis}

It is clear that this virus can be transmitted via semen (Kahrs et al, 1980). Many studs have sought to eliminate reactors over a number of years, but where genetic merit has encouraged the retention of such bulls, cultural tests, or occasionally biological tests, have been used to prove the semen free of an infective dose.

At Avoncroft, where we have in the past maintained a separate stud premises for seropositive bulls, many imported as vaccinates from Canada, but others British-born and not vaccinated, on only 2 occasions out of $>10000$ ejaculates cultured has virus been demonstrated. No clinical infection has ever been seen. It is thought likely that the current cultural test has a level of sensitivity approximately equivalent to an infective dose. However, the Swiss experience (Kupferschmied et al, 1986) where frozen imported semen tested culturally negative caused seroconversion (and reduced conception) in females inseminated 
does raise doubts about the adequacy of the sensitivity of current tests.

The Directive seeks to eliminate IBR serologically positive bulls from national studs. With such a high prevalence of reactors in herds throughout Europe, the acquisition of young bulls as potential sires completely free of IBR viral infection can prove difficult. The Danes have succeeded in almost eradicating the disease from their nation herd by a slaughter policy in the early 80 s and using a highly sensitive serological test (Andersen, 1989). Inevitably such testing will remove a small percentage of animals that are in fact not infected. These measures are of course expensive, but the wisdom of the policy is underlined by more recent American work which confirms that a percentage of young bulls negative on routine SNT and Elisa testing are shown by more sensitive serological tests to harbour latent virus (Howard, 1990, personal communication). Guérin in France (1989) has also reported latent virus emerging in adult bulls.

Where bulls in a progeny testing programme have to leave the main stud whilst awaiting the test, some organizations have had to resort to vaccination. As an interim measure, the Directive permits the continual use of such seropositive sires, with the proviso that all ejaculates are cultured in the laboratory to determine freedom from virus.

Although the Directive currently allows for the marketing of semen from reactors that have been present on studs before 1990 , all are most likely to be phased out by 1992. The fate of semen from such bulls still has to be settled. Member states are entitled to refuse semen of this status, but there is pressure to utilize rather than discard in some member states where imported positive bulls have shown an exciting progeny performance, or where seroconversion has suddenly arisen in a major stud. Many breeders in the UK, although subscribing to the ideal of disease-free semen, would prefer to see IBR semen still marketable with the current laboratory tests for virus, until there is a more realistic way of eliminating the disease from the female herd. It is likely that more sophisticated virus detection in semen will precede major improvements in vaccine production (Howard, 1991, personal communication).

\section{Leptospirosis}

The spread of this disease by natural service is established (Ellis et al, 1985), and therefore despite processing procedures working against the viability of leptospirosis in frozen semen, donor sires should be free of the infection.

The microscopic agglutination test is not fully reliable in detecting carrier ruminants (Ellis et al, 1981), and yet streptomycin is neither the best treatment drug of choice, nor is it guaranteed to eliminate infection (Ellis et al, 1985). Most studs in member states have, in the past, confirmed freedom of infection on all new entries by a negative serological test. This, coupled with due attention to antibiotic levels and processing time in the laboratory, have given sufficient confidence. There is no published data to suggest otherwise.

The Directive does not request serological testing, but does demand heavy streptomycin treatment; $25 \mathrm{mg}$ per kilo is 3 times the maximum recommended dose. Two recent studies of semen output after treatment (Abbitt et al, 1984; Howard, 1990, personal communication) have shown no reduced semen quality, but anecdotes and the past history of the drug with its effect on the eighth nerve still provoke distrust. Responsible studs will 
still serologically test incoming bulls to confirm a negative status, and the widespread use of such a controversial antibiotic in uninfected animals will remain of concern.

\section{IDENTIFICATION, STORAGE AND DISTRIBUTION OF REGISTERED SEMEN}

Free movement of frozen semen means the necessity for a standard system of identification. This has now been agreed upon (table I) and should clearly differentiate between semen collected under the Directive and that collected as nonregistered semen.

Registered semen collected under the terms of the Directive since January 1990 is stored separately from other categories in quarantine and in central storage units. It is the only semen collected since that date that can be marketed between member states. A standardized health certificate is now regularly used and import permits have been dispensed with.

Semen collected before 1990 may be traded under the old terms, a different set of rules for each country, but with any relevant additions to the health requirements.

\section{NON-REGISTERED SEMEN}

Since the Directive came into operation, some studs have remained non-registered, still perhaps operating under their original system of health control and semen processing. A limited amount of semen collecting "on farm" under licence is also still practised.

This non-registered semen in the same category as that collected on registered studs within the first $30 \mathrm{~d}$, is stored separately from registered semen, and may only be marketable within the member state of production.

The introduction of the single market in January 1993 could rule out the use of this non-registered category. Breeders are calling for its continued use, certainly in the country of origin, but lawyers may argue that in the single market it is contradictory to refer to restricted use in one state only.

There is considerable uncertainty about the use of non-registered semen after the implementation of the single market. Veterinary authorities in the different member states vary considerably in the importance that they are placing on these matters. It is regrettable that the Council are taking such a time to come to a majority decision, and make a firm ruling on the future of these categories of semen.

Table I. Standard system of identification.

\begin{tabular}{llllll}
\hline Bung end & & & & \multicolumn{2}{c}{ Crimped end } \\
$90-001$ & UK02 & 0100527283 & Thirlgreen Mayfair & FB & 4103 \\
\hline 1 & 2 & 3 & 4 & 5 & 6 \\
\hline
\end{tabular}

1. Date of batch processing; 2. Processing unit identity code (EEC regulations); 3. Bull herd book number; 4. Name of bull; 5. Breed code; 6 . Bull code number for computerisation/record purposes (after Merson, 1990). 


\section{SEMEN FROM THIRD COUNTRIES}

North America is the source of most of the semen imported into countries of the EEC in the last decade. North American studs have been aware of the proposed EEC policy and have made great strides in setting up main units or satellite units serologically free for EBL and IBR. Although such studs have been officially visited by veterinarians of the Community Commission only recently, the "no favoured status" rule is now being implemented. This states that any third country seeking markets within the EEC must as a minimum adopt the practice of the Semen Directive. Beyond this, of course, attention is paid to other disease present in that third country that could present a threat.

Blue tongue, whose vectors are usually present some time during the year in countries within $40^{\circ} \mathrm{N}$ and $35^{\circ} \mathrm{S}$ of the equator, will always be a problem in the southern part of the USA, and furthermore will present a threat to the Canadian cattle population during the fly season where livestock can be moved quickly from south to north.

In the UK there has always been a great wariness about the danger of importing this virus in semen to a country where the sheep population has been greater than all the other member states combined and potential vectors might be present. There is still much uncertainty over the carrier state in seropositive bulls. It is likely there will be a Community decision to accept only semen from seronegative donors tested pre and post collection.

The style of the Directive and its likely success in standardizing the health status of semen originating from the EEC is viewed favourably by an increasing number of third countries. It is likely to be adopted as a measure of acceptability by other veterinary importing authorities.

\section{SEMEN QUALITY CONTROL AND GENETIC DEFECTS}

The Directive pays no attention to semen quality control. Veterinary supervision of most European studs involves attention to semen quality of the donor sires, including a regular clinical examination, but only in a few studs is there an independent assessment of semen quality. Although all would subscribe to a basic level of semen quality, as demonstrated in the laboratory, attention to this point at Directive level will have more relevance when more meaningful tests are available in vitro for the determination of fertility.

Finally, it would be pertinent to mention that the widespread distribution of genetic defects must be closely guarded against. The Directive pays no attention to this, and it is noteworthy that governments no longer act as guardians. At one level one might say "buyer beware", but it is in the interests of all cattle breeding organizations that genetic defects when suspected are examined quickly and necessary measures taken. This once again illustrates the importance in this hard commercial world of all veterinary health matters being freely available to all bodies. In this way confidence will be built up.

\section{REFERENCES}

Abbitt B, Berndtson WE, Seidel GE Jr (1984) Effect of dihydrostreptomycin or oxytetracycline on reproductive capacity of bulls. Am J Vet Res 45, 2243-2246

Andersen JB (1989) Details of national stud testing. Proc 1st Sci Meet Eur Vets Al, Luxembourg $\mathrm{p} 20$

Ellis WA, Montgomery J, Cassells J A (1985) Dihydrotreptomycin treatment of bovine carriers of Leptospira interrogans serovar hardjo. Res Vet Sci 39, 292-295

Ellis WA, O'Brien JJ, Cassells J (1981) Role of cattle in the maintenance of Leptospira inter. 
rogans serotype hardjo infection in Northern Ireland. Vet Rec 108, 555-557

Ellis WA, Songer JG, Montgomery J, Cassells JA (1985) Prevalence of Leptospira interrogans serovar hardjo in the genital and urinary tracts of non-pregnant cattle. Vet Rec 118, 11-13

Guerin B (1989) Effects on reproduction and control in Al studs. Proc 1st Sci Meet Eur Vets Al, Luxembourg, p 5

Hare WCD (1985) Diseases transmissible by semen and embryo transfer techniques. OIE (Paris) Tech Ser 4, 4-13
Kahrs RF, Gibbs EPJ, Larsen RE (1980) The search for viruses in bovine semen, a review. Theriogenology 14 (2), 151-165

Kupferschmied HU, Kihm U, Bachman P, Müller $\mathrm{KH}$, Ackerman M (1986) Transmission of IBR/IPV virus in bovine semen: a case report. Theriogenology 25, 439-443

Merson P (1990) Identification of semen straws. Proc 2nd Sci Meet Eur Vets Al, Denmark, p 93

Porter ARW (1990) Understanding 1992. In: Veterinary Annual, 30th Issue. Butterworth, 1822 